Отже, у ціннісно-смисловій сфері студентів-філологів відображаються найбільш вагомі для них життєві пріоритети, відповідно до яких відбувається осмислення життєвих подій та вибудовується стратегія життєвої і професійної самореалізації. Становленню основ смислоорієнтаційної та смислорегулятивної діяльності майбутніх фахівців сприяють такі технології, як ділові ігри, афірмації та проблемно-рефлексивний полілог, що здійснюють позитивний влив на формування аксіологічної сфери студентів.

\title{
Література:
}

1. Радчук Г. К. Психологічні засади професійного аксіогенезу особистості. Психологія особистості. 2012. № 1 (3). С. 138-150.

2. Федух I. С. Ціннісно-смисловий аспект оволодіння іноземною мовою студентами ВНЗ. Проблеми сучасної педагогічної освіти. URL: http://science.cfuv.ru/wp-content/uploads/2015/10/111.pdf (дата звернення: 24.09.2020).

3. Ярмакеев И. Э. Моделирование личности современного учителя : ценностно-смысловой аспект. Казань : Изд-во Казан. ун-та, 2004. 424 с.

DOI https://doi.org/10.30525/978-9934-588-80-8-2.47

\section{MEANS OF FORMING STUDENTS' SOCIAL COMPETENCE IN THE PROCESS OF TEACHING FOREIGN LITERATURE}

\author{
Stepanenko O. K. \\ Candidate of Philological Sciences, Associate Professor, \\ Senior Lecturer at the Department of Social and Humanitarian Science \\ Communal Institution of Higher Education «Dnipro Academy \\ of Continuing Education» of Dnipropetrovsk Regional Council \\ Dnipro, Ukraine
}

The aim of the work is to characterize the effective means of forming students' social competence while teaching foreign literature. One of the central tasks of modern education is to ensure the student's social adaptation, his or her adaptation to the real conditions of social life, to the structure of social relations and activities. Socialization is a person's lifelong development while interacting with the environment. This involves the assimilation and reproduction of social norms and cultural values as well as the individual's self-development and self-realization in the society which he 
or she belongs to. In modern society, which is rapidly evolving and changing, socialization is often spontaneous and individual development in the process of mastering social experience is replaced by the formation of personal stereotypes. At the same time society needs a business-like, initiative, creative, active personality, able to realize his or her potential in the professional sphere and interpersonal relationships [6].

The new State Standard of Basic and Complete General Secondary Education has standardized the need to organize training grounded on competency-based, person-centered and activity-based approaches. This is the document that interprets competence as a student's integrated ability acquired in the learning process which consists of knowledge, skills, experience, values and attitudes that can be fully implemented in practice. At the same time a person-centered approach to teaching ensures developing students' academic, socio-cultural, socio-psychological and other abilities [3].

The purpose of basic general secondary education is students' development and socialization, forming national identity, culture, worldviews, skills of practical use of experience gained through reading, awareness of the importance of reading as a factor in their own personality development and socialization, environmental thinking and behavior, creativity, research and life support skills, ability to self-development and self-learning in the context of global change and challenges.

Competency-based approach contributes to forming key and subject competences. The activity-based approach is aimed at developing the student's skills and abilities, applying acquired knowledge in practical situations, searching for ways to integrate into the socio-cultural and natural environment.

The tasks of studying the discipline «Foreign Literature» are promoting the formation of values-based attitude to what is happening around, understanding that it is important to live values.

Recognition of the competency-based approach as the leading one in teaching presupposes the formation of not only subject but also key competences, shifting the emphasis on the activity educational result. Given the essence of this approach, knowledge should be a tool in solving life problems, a means of students' personal development, socialization, successful professional development and arranging personal life. Therefore, the content of educational material is determined by its effectiveness, its need outside the school.

Thus, the ability to cooperate in a group and team, mobility, the ability to adapt and define personal goals and perform various roles and functions in the team, to plan, to develop and to implement social projects of individual and collective action; ability to determine and to implement the purpose of 180 
communication depending on the circumstances; to maintain relationships; to solve problems in different life situations are the main components of a student's social competence, which are practiced while literature lessons.

The concept of «social competence» is an integration of the terms: «social» that comes from Latin «socialis» which means «sociable, one that belongs to society, associated with the life and people relationships in society» [5, p. 184], and "compete» which means "perfect mastery of business, knowledge». This category of concepts can be interpreted as the possession of social powers, social knowledge, the presence of social authority or a certain level of social competence that allows people to exist and act in society.

Social competence is determined by the ability to explain social situations; to determine the personal characteristics and emotional state of others; the ability to choose adequate ways of communication with them and implement them while interacting.

Social competence is efficiency or adequacy with which an individual is able to respond to various problem situations he or she faces.

Social competence is understood as a human quality formed while mastering ideas and knowledge about social reality, active and creative development of social relations at different stages and in different types of social interaction, and it is interpreted as the assimilation of ethical norms that are the basis for building and regulating interpersonal and intrapersonal social positions, relationships. Formation and development of schoolchildren's social competence is one of the main tasks of modern school system [5, p. 184].

The formation of students' social competence in foreign literature lessons will promote applying critical thinking methods.

Critical thinking is a set of mental operations characterized by a person's ability to analyze, compare, synthesize, evaluate information from any source, see problems, ask questions, hypothesize and evaluate alternatives, make conscious choices, make decisions and justify them. These mental operations can and should be taught, and then they should be improved and trained [2, p. 14].

Applying the «Magic Chair « method will help students get used to the image of any character. Students should tell a story from the first person about themselves, their lives and relationships in the family of the characters. This encourages other students to ask questions to the imaginary character. Thus, a constructive dialogue is formed between the participants.

«Brainstorming» is a method of solving the creative problem of the work. This technique activates students' attention, encourages creativity, 
promotes the ability to freely express their thoughts, and develops logic as well as communication skills.

Writing student creative works occupies a prominent place when forming a spiritually rich personality.

It is effective to use the «Brownian motion» in foreign literature lessons; this is a technique by which students study a large amount of theoretical material in a short period of time and explain its content to classmates, in other words «learning by teaching others». The class is grouped together. Each group receives a card with the text. After reading and discussing the content of the text, group members move on to other groups and share the information with them. The process of transition from group to group is completed after each student in the class has received the full amount of theoretical material being studied.

Thus, traditional education was created at the request of industrial society. It was aimed at fulfilling the existing social order at the time, for example, to give the student certain knowledge, skills and abilities. Having mastered them, he or she was able to work successfully at the factory, construction activities and other industries. That was enough yesterday, but not enough today. We must realize that the information society puts demands radically different from traditional ones.

Tomorrow's technologies require people who can make critical decisions [4, p. 53]. This is the social order today, even if it is not fully understood and accepted in the Ukrainian reality. Nowadays the teacher must think about future, about the socialization of the student in modern conditions.

\section{References:}

1. Crawford A., Saul W., Mathews S., Makinster J. Teaching and learning strategies for the thinking classroom / preface. O. I. Pometun. Kyiv: Pleyady, 2006. 220 p. URL: https://osvita.ua/doc/files/news/487/48780/ KritichneView.pdf (Accessed on: Sept.08.2020). (in Ukrainian)

2. Pometun O., Sushchenko I. Fundamentals of critical thinking: a guide for teachers. Kyiv: Lira, 2016. P. 14-15. (in Ukrainian)

3. Smolinchuk L. S. Competency-based approach to the evaluation of the educational outcomes. Problems of modern pedagogical education. 2012. Issue 37(1). Pp 258-261. URL: http://nbuv.gov.ua/UJRN/pspo_2012_ 37\%281\%29_48 (Accessed on: Sept.08.2020). (in Ukrainian)

4. Tarutina $Z$. Training professionals in the context of globalization, the Internet and a new wave of progress in the exact sciences. Higher education in Ukraine. 2012. № 2(45). Pp. 50-54. (in Ukrainian)

5. Fedorutz M. V. B. Formation of schoolchildren's social competence in the process of partnership of secondary schools and families. Scientific 182 
Bulletin of Uzhhorod National University. Series «Pedagogy, social work». 2015. Issue. 37. Pp 184-186. (in Ukrainian)

6. Shevchuk O. The role of school in the socialization of the individual. Psychological and pedagogical problems of rural school. Psychology and pedagogy. Issue. 52. 2015. URL: https://library.udpu.edu.ua/library_files/ psuh_pedagog_probl_silsk_shkolu/53/60.pdf (Accessed on: Sept.09.2020). (in Ukrainian)

DOI https://doi.org/10.30525/978-9934-588-80-8-2.48

\title{
ОСОБЛИВОСТІ ПРОФЕСІЙНОЇ ПІДГОТОВКИ ІНОЗЕМНИХ СТУДЕНТІВ 3 МІКРОБІОЛОГІЇ, ВІРУСОЛОГІЇ ТА ІМУНОЛОГІЇ В МЕДИЧНИХ УНІВЕРСИТЕТАХ УКРАЇНИ
}

\author{
Текдемір I. O. \\ асистент кафедри громадського здоров'я та мікробіології \\ ПВНЗ «Київський медичний університет» \\ м. Київ, Україна
}

Щороку до вищих навчальних закладів України приїжджають вчитися все більше іноземних студентів. Згідно з даними Міністерства освіти і науки, молоді та спорту України, щорічний приріст іноземних студентів становить $10 \%$, а в цілому в українських ВНЗ навчається близько 48 тисяч студентів 3 інших країн. Викладання у групах іноземних студентів вимагає ретельної організації навчального процесу. Викладачі, проводячи заняття, обов'язково враховують культурні особливості, релігійні погляди та традиції іноземних студентів. Особливо це важливо для перших курсів, коли потрібно донести до них матеріал предмета 3 використанням зрозумілих прикладів та доступної термінології, у той же час збагачуючи їх словниковий запас [2, с. 153].

Медична освіта має бути орієнтована на розвиток творчої особистості, яка здатна самостійно оволодівати новітніми досягненнями науки і плідно застосовувати їх на практиці.

Предмет «Мікробіологія, вірусологія та імунологія» $\epsilon$ однією із базових дисциплін доклінічної підготовки майбутніх лікарів, стоматологів та фармацевтів. Вивчення дисципліни передбачене на другомутретьому курсах медичних вищих навчальних закладів. Викладання мікробіології, вірусології та імунології проводиться згідно з типовою програмою і навчальним планом, на основі яких розроблена робоча 